\title{
Relationship of Density of Specific Prostate Antigen (DPSA) with Prostate Histopathology: A Comparative Study of Patients Addressed in a School Hospital
}

\author{
Marcos Benedito Figueiredo Brandão1, Maria Benedita Figueiredo Brandão², \\ Elias Sobreira Sathler ${ }^{1,3}$, Richard Raphael Borges Tavares Vieira ${ }^{1,3}$, Carolina Cadinelli Vieira ${ }^{1,3}$, \\ Pedro Kozlowsky de Alencar ${ }^{1,3}$, Marcus Vinicius de Mello Pinto4, \\ Lamara Laguardia Valente Rocha5, Lina Claudia Pereira Lopes ${ }^{1}$, \\ Daniel Almeida da Costa ${ }^{1,3}$, Carlos Henrique Diniz Branco ${ }^{1,3}$ \\ ${ }^{1}$ Luiz Gioseffi Jannuzzi School Hospital of the Dom Andre Arcoverde Foundation, Valença, Brazil \\ ${ }^{2}$ Universidade Estácio de Sá, Rio de Janeiro, Brazil \\ ${ }^{3}$ The Medical School at the Center of Higher Education of Valença, Valença, Brazil \\ ${ }^{4}$ The Cellurare Institute Center of Laser Treatment and Cell Therapy, Petrópolis, Brazil \\ ${ }^{5}$ The Medical School at the Health Sciences Institute of the University Center of Caratinga, Caratinga, Brazil \\ Email: figueiredobrandao@hotmail.com,mah_brandao_@hotmail.com, essathler@hotmail.com,rrbtv@hotmail.com, \\ cadimed@outlook.com, pekozlowsky@gmail.com,orofacial_1@hotmail.com, lamara.laguardia@gmail.com, \\ linalopes217@gmail.com, acosttta@icloud.com,chenriquebranco@uol.com.br
}

How to cite this paper: Brandão, M.B.F., Brandão, M.B.F., Sathler, E.S., Vieira, R.R.B.T., Vieira, C.C., de Alencar, P.K., de Mello Pinto, M.V., Rocha, L.L.V., Lopes, L.C.P., da Costa, D.A. and Branco, C.H.D. (2017) Relationship of Density of Specific Prostate Antigen (DPSA) with Prostate Histopathology: A Comparative Study of Patients Addressed in a School Hospital. Journal of Biosciences and Medicines, 5, 105-111. https://doi.org/10.4236/jbm.2017.53011

Received: February 6, 2017

Accepted: March 20, 2017

Published: March 23, 2017

Copyright (c) 2017 by authors and Scientific Research Publishing Inc. This work is licensed under the Creative Commons Attribution International License (CC BY 4.0).

http://creativecommons.org/licenses/by/4.0/

\section{Abstract}

Background: The prostate is the site of problems that have great clinical relevance. Beside this, the alterations in their volume can be divided into benign or malignant pathologies, but of multifactorial cause and there is no examination that alone is reliable for the diagnosis. Despite the evolution of the various methods of diagnostic imaging in the evaluation of pelvic diseases, the diagnosis of prostate cancer still requires histological confirmation obtained by transrectal ultrasound guided biopsy, a procedure that is generally safe and well tolerated by the patients. The most common histological type found in prostate biopsies is adenocarcinoma. Methodology: The objective of this study was to study the values of density of the prostate-specific antigen (DPSA) compared to histopathological results of prostate biopsy, patients attended at the Urology Outpatient Clinic of the Luiz Gioseffi Jannuzzi School Hospital from 1999 to 2007, using Exploratory, retrospective and documentary descriptive study. The sample was divided into groups of patients with adenocarcinoma and patients without adenocarcinoma, who presented only benign prostatic hyperplasia. Results: Of the 251 patients undergoing prostate biopsy, 124 were diagnosed with adenocarcinoma and 127 without adenocarcinoma. 
It was observed in this study that the DPSA was higher in adenocarcinoma than in the cases of patients with prostatic hyperplasia alone, and could therefore be used as an auxiliary tool in both diagnosis and follow-up of patients with adenocarcinoma. Conclusion: In this study, it can be observed that DPSA was higher in patients presenting with adenocarcinoma than in patients presenting only Benign Prostatic Hyperplasia (BPH), reinforcing its promising role to assist in the diagnosis and follow-up of patients with adenocarcinoma.

\section{Keywords}

Prostate Cancer, Adenocarcinoma, Benign Prostatic Hyperplasia, Prostate Biopsy

\section{Introduction}

The prostate is a small organ about $3 \mathrm{~cm}$ long that is located in the pelvis and weighs about $20 \mathrm{~g}$ in the healthy adult. Its constitution corresponds to $2 / 3$ glandular and 1/3 fibromuscular, also having a dense fibrous capsule, surrounded by a continuous prostatic sheath with puboprostatic ligaments. Among the pathologies that afflict it, cancer, benign hyperplasia and prostatites are noteworthy [1].

Prostate cancer is the second most common in male incidence and the 6th most frequent cause of death in the world among the adult male population and adenocarcinoma represents the most common type, originating from acinar cells of the prostate. It is treated as an aging disease, rarely occurring in men under 40 years of age and its incidence is increasing, with peak in the eighth decade of life. Natural history is influenced by variables such as age of the patient, stage and degree of cancer, presence of clinical or other malignancies, genetic predisposition, hormonal influences, dietary, environmental factors and infectious agents, with great variability in biological behavior and metastatic potential of this neoplasm, which causes controversy about the appropriate treatment in several stages of prostate cancer [2] [3].

In many cases, symptoms arise only when the tumor is anatomically highly developed or metastatic, bringing to the fore the importance of screening and early detection measures in asymptomatic patients before clinical manifestations, since a greater number of patients are detected in this phase [4] [5].

On the other hand, Benign Prostatic Hyperplasia (BPH) is another very common condition in elderly men, which can cause different degrees of compression in the prostatic urethra and, consequently, urinary retention with obstructive or irritative micturition symptoms [2]. It generally responds well to clinical management with alpha blocker, despite controversies about the profile of patients responsive or not to this therapy, the metabolic syndrome may be related to $\mathrm{BPH}$ and adversely affect the alpha blocker response [6]. 
In Brazil, the increase in life expectancy, the improvement and evolution of the diagnostic methods and the quality of the country's information systems achieved in recent years are related to the dissemination of prostate cancer screening with rectal examination, dosage of the specific prostatic antigen (PSA) and transrectal ultrasonography (USG-TR) to assist the best biopsy area, which explains the increase in incidence rates over the years [4].

PSA is the most important marker for the diagnosis and initial follow-up of prostate cancer, despite the difficulties to distinguish between cases of benign prostatic hyperplasia $(\mathrm{BPH})$ and a considerable number of false positives and unnecessary biopsies [5]. In contrast, more tools were introduced to aid in screening and decrease the number of unnecessary biopsies such as dosage and calculation of the PSA Free/PSA Total Ratio, PSA Velocity (VPSA) and PSA Density (DPSA) [7].

VPSA is defined as a change in serum PSA values over a period of time and is generally less than $0.10 \mathrm{ng} / \mathrm{mL}$. However, BPH interferes with the speed of PSA due to rapid growth velocity, leading to increased PSA due to enlargement of the gland and not due to tumor enlargement [8].

DPSA was introduced to increase the sensitivity and specificity of PSA and is expressed by the ratio of prostate volume to serum PSA value assessed by USGTR, reflecting activity in the prostate transition zone. Its limitations are the failure to accurately determine the prostate volume by USG-TR and the variability of glandular content versus stroma that varies from gland to gland. In the calculation of DPSA, serum PSA $(\mathrm{ng} / \mathrm{mL})$ is divided by the prostate volume $\left(\mathrm{cm}^{3}\right)$ evaluated by USG-TR ultrasound with cut-off point has been $0.15 \mathrm{ng} / \mathrm{mL}$ [9] [10].

The objective of this study was to study the DPSA values comparing to histopathological results of prostate biopsy of patients followed at the Urology Outpatient Clinic of the Luiz Gioseffi Jannuzzi School Hospital (HELGJ) from 1999 to 2007.

\section{Methodology}

This study was initially carried out a literary review on the subject in books and articles published in periodicals indexed to PubMed and Scielo. After that, a descriptive exploratory and retrospective documentary study was carried out.

Data were collected from patients seen at the Outpatient Clinic at HELGJ and with examinations performed during between 1999 and 2007 due to the greater number of information available in the medical records of this period. As selection criteria for inclusion in the study were those who used PSA dosage, DPSA and prostate biopsy, and those patient records that did not contain any of these criteria were excluded from the study.

In order to collect data, the following variables were evaluated: laboratory values of PSA ( $\mathrm{ng} / \mathrm{mL})$, of DPSA $(\mathrm{ng} / \mathrm{mL})$-which correspond to the division between total PSA and prostate volume $\left(\mathrm{cm}^{3}\right)$, and of prostate volume $\left(\mathrm{cm}^{3}\right)$ of histopathological studies. 
For the analysis of the information, patients' charts were selected with alterations in the variables mentioned above, correlating the parameters with the relevant literature.

The study was submitted to the Ethics and Research Committee of the Faculty of Medicine of Valença (FMV), being approved under No. 1656834.

The USG exams were performed with the Medson model SA-6000C, with the prostate and bladder being examined abdominally with a convex abdominal transducer of $3.5-5.0 \mathrm{MHz}$ and the transrectal with a $6.5 \mathrm{MHz}$ endocavitary transducer.

The prostate biopsies were performed with Atru Core I Uro ${ }^{\circledR} 18 \mathrm{GA} / 25 \mathrm{~cm}$ biopsy needle from the manufacturer Md Tech, a biopsy gun model Tech 7633, made by sextant with saturation of the areas considered suspicious and under local anesthesia with xylocaine at $2 \%$.

Data were compiled using Excel software, an integral part of Microsoft ${ }^{\otimes}$ Office 2010 Professional and data analysis was performed by comparison and analysis of variance (ANOVA).

\section{Results}

A total of 328 medical records were analyzed, of which 77 were excluded because they did not contain data that contributed to the study. The mean age of the patients included in the analysis was 72.5 years \pm 20.5 years, with a mean total PSA serum level of $23.72 \pm 31.31 \mathrm{ng} / \mathrm{mL}$ and a mean prostatic volume of $54.29 \mathrm{~cm}^{3}$ (Table 1).

It should be clarified that a mean of 11.4 fragments per patient was obtained for histopathological exams. The smallest number was 4 and the largest was 32 fragments per patient, the material was paraffin-embedded and stained with hematoxylin and eosin.

The sample was divided into 2 groups: patients with adenocarcinoma and without adenocarcinoma. Of the 251 patients undergoing prostate biopsy, 124 were diagnosed with adenocarcinoma and 127 were diagnosed without adenocarcinoma, presenting only BPH. Patients with adenocarcinoma and with BPH were included only in the adenocarcinoma group.

The sum of DPSA values of adenocarcinoma group was 147.26 and sum of DPSA values of without adenocarcinoma group was 32.53 . The mean DPSA values were 1.19 for adenocarcinoma cases and 0.26 for cases in which the patient had only BPH and variance of 16.04 and 0.17 , respectively.

We also tested the variability of the groups through ANOVA. The critical F > $\mathrm{F}$ value means that there is a significant relationship between the DPSA value

Table 1. Means of age, total PSA and prostatic volume of all patients included in study.

\begin{tabular}{cccc}
\hline & Age & Total PSA & Prostatic Volume \\
\hline Mean & 72.5 & 23.72 & 54.29 \\
Standard Deviation & \pm 20.5 & \pm 31.31 & \\
\hline
\end{tabular}


and the adenocarcinoma of the prostate, demonstrating that there is an important relationship between the DPSA test results and the occurrence of the neoplasia (Table 2 and Table 3).

In the drawing of the graph, isolated values were extracted in the two samples, as they generated discrepancy. There was an increase in DPSA values proportional to the increasing number of patients with adenocarcinoma and $\mathrm{BPH}$, respectively, but this increase was much more pronounced in patients in the adenocarcinoma group (Figure 1).

\section{Discussion}

Due to the considerable prevalence of the histological type, this study will treat from here prostate cancer as adenocarcinoma, where the levels of PSA in the blood plasma are larger and there is correlation with the prostate volume [11].

According to Rhoden and Averbeck (2010), the mean age at which prostate

Table 2. Summary of statistical differences between groups tested.

\begin{tabular}{ccccc}
\hline Group & Score & Sum & Media DPSA & Variance \\
\hline Adenocarcinoma & 124 & 147.26 & 1.19 & 16.04 \\
BPH & 127 & 32.53 & 0.26 & 0.17 \\
\hline
\end{tabular}

Table 3. Variance analysis (ANOVA) between and within groups tested.

\begin{tabular}{ccccccc}
\hline Source of Variation & $S Q$ & $G L$ & $M Q$ & $F$ & $p$ & Critical F \\
\hline Between groups & 54.43 & 1 & 54.43 & 6.79 & 0.01 & 3.88 \\
Within groups & 1995.24 & 249 & 8.01 & & - & - \\
Total & 2049.67 & 250 & & & \\
\hline
\end{tabular}

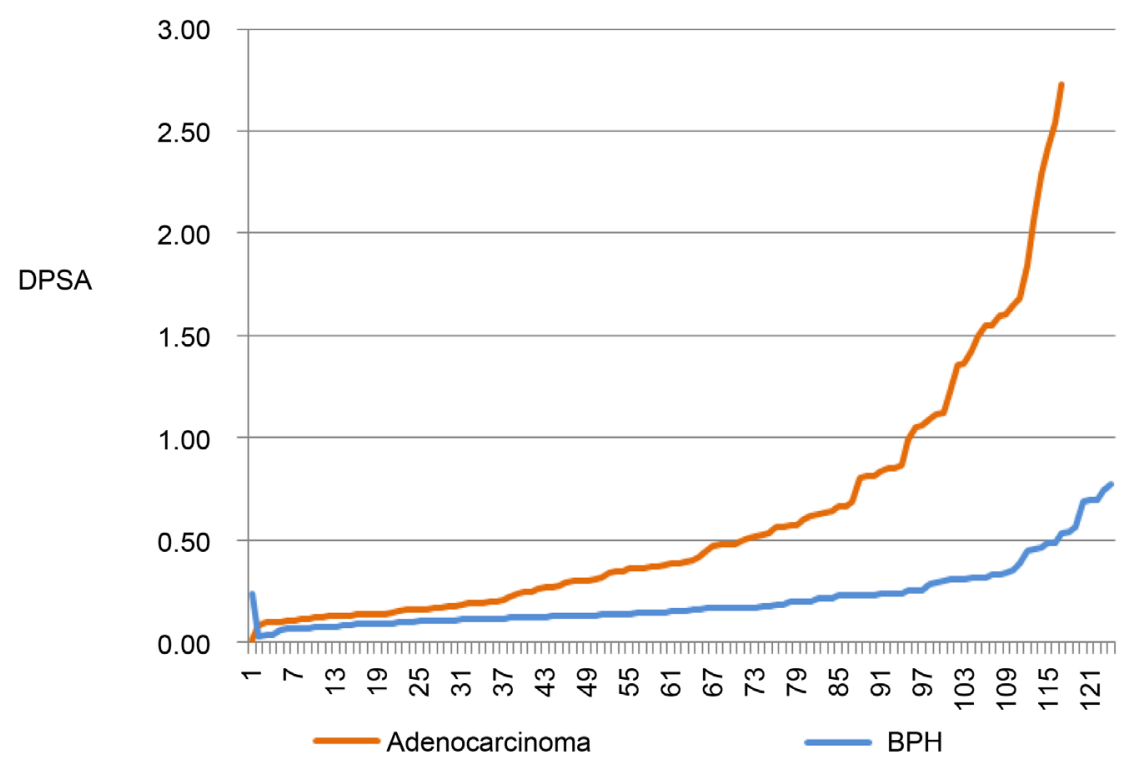

Figure 1. Graph sample of patients with adenocarcinoma and BPH with respective DPSA values followed at the HELJG Outpatient Urology Clinic between March 1999 and January 2007. 
cancer is most commonly diagnosed is around 72 - 74 years and according to Fernandes et al. (2014), on average at 74 years; both studies corroborating our results [7].

Still, according to Fernandes et al. (2014), some risk behaviors for prostate cancer that may be mentioned include inadequate feeding, smoking, alcoholic beverage intake, and average time spent on care for more than 30 days. Caucasian, low schooling, retirement and family cohabitation were predominant characteristics in their patients [13].

On the other hand, in relation to the value of PSA, NettoJr and Wroclawski (2010) and Nassif (2009) admit that normal is up to $4 \mathrm{ng} / \mathrm{ml}$ (11) (14), much lower than that found in our study.

We did not find in the present sample cases of hyperplasia with DPSA $>4.33$, which was found in only one patient in the present case, considered, therefore, outside the standard curve.

In the patients diagnosed with adenocarcinoma, 23 had DPSA $<0.18$, corresponding to $18 \%$ of the series, which demonstrates an intimate relationship between the elevation of DPSA and prostate cancer, corroborating with studies by Nassif et al. (2013) and Moreira (2015) [5] [10].

It was also evidencing higher prostate volume in patients with benign tumors, which may be related to the higher prevalence of $\mathrm{BPH}$.

\section{Final Considerations}

PSA dosage, despite its limitations, remains the main tool for screening and is also useful in monitoring prostate cancer, especially in association with the calculation of PSA Free/PSA Total Ratio and DPSA [4] [5] [12] [14] [15] [16].

In this study, it can be observed that DPSA was higher in patients presenting with adenocarcinoma than in patients presenting only $\mathrm{BPH}$, reinforcing its promising role to assist in the diagnosis and follow-up of patients with adenocarcinoma.

However, among the many uncertainties that are encountered when dealing with patients known to be carriers of prostate cancer, are the parameters to be used in their therapeutic conduction. There are no known tests that are highly reliable in isolation.

A fact to be taken into account is that the USG-TR biopsy examination is subject to method failures and has not been evaluated for hormone suppression therapy, which would directly influence the results.

\section{Acknowledgements}

Thanks to the Center of Higher Education of Valença of Dom André Arcoverde Foundation.

\section{References}

[1] Moore, K.L. and Dalley, A.F. (2007) Anatomia orientada para a clínica. 4a ed., 326.

[2] Tanagho, A. and McAninch, J.W.S. (1994) Urologia geral. 13a ed., 303. 
[3] Sócrates de Castro, H.A., et al. (2011) Contribuição da densidade do PSA para predizer o câncer de próstata em pacientes com valores de PSA entre 2.6 e 10.0 ng/ml. Radiologia Brasileira, 44, 205-209.

https://doi.org/10.1590/S0100-39842011000400003

[4] Brasil. Ministério da Saúde. Estimativa 2014: Incidência de Câncer no Brasil. Instituto Nacional de Câncer José Alencar Gomes da Silva, Coordenação de Prevenção e Vigilância. INCA, Rio de Janeiro.

http://www.inca.gov.br/rbc/n_60/v01/pdf/11-resenha-estimativa-2014-incidencia-d e-cancer-no-brasil.pdf

[5] Nassif, A.E., Radaelli, M.R., Lins, L.F.C. and Angelo, V.F. (2013) Utilização do Antígeno Prostático Específico no Diagnóstico do Câncer de Próstata. Brazilian Journal of Surgery and Clinical Research, 5, 17-21.

[6] Akin, Y., et al. (2017) Preliminary Assessment of Neck Circumference in Benign Prostatic Hyperplasia in Patients with Metabolic Syndrome. International Brazilian Journal of Urology, 43, 95-103.

[7] Gimba, E.R.P. (2013) Além da era do PSA: Novos biomarcadores para câncer de próstata. Urologia Essencial, 3, 4-11.

[8] Carter, R.H.B., Ferrucci, L., Kettermann, A., Landis, S.P., Wright, E.J., Epstein, J.I., Trock, B.J. and Metter, E.J. (2006) Detection of Life-Threatening Prostate Cancer with Prostate-Specific Antigen Velocity during a Window of Curability. Journal of the National Cancer Institute, 98, 1521-1527. https://doi.org/10.1093/jnci/djj410

[9] Sócrates de Castro, H.A., Lared, W., Shigueoka, D.C., Mourão, J.E. and Ajzen, S. (2011) Contribuição da densidade do PSA para predizer o câncer da próstata em pacientes com valores de PSA entre 2.6 e $10.0 \mathrm{ng} / \mathrm{ml}$. Radiologia Brasileira, 4, 205-209. https://doi.org/10.1590/S0100-39842011000400003

[10] Moreira, H.A. (2015) Um novo índice para detecção do câncer de próstata (razão entre densidade do PSA e PSA livre sobre o PSA total). Tese de Doutorado, Almeida SHM, Orientador, 15.

[11] Netto Jr., N.R. and Wroclawski, E.R. (2000) Urologia fundamentos para o clínico. Editora Sarvier, 216.

[12] Rhoden, E.L. and Averbeck, M.A. (2010) Câncer de próstata localizado. Revista da AMRIGS, Porto Alegre, 54, 92-99.

[13] Fernandes, M.V., Martins, J.T., Cardelli, A.A.M., Marcon, S.S. and Ribeiro, R.P. (2014) Perfil Epidemiológico do Homem com Câncer de Próstata Atendido em um Hospital Universitário. Cogitare Enfermagem, 19, 333-340.

[14] Nassif, A.E. (2009) Análise do valor prognóstico dos marcadores imunohistoquímicos P27, MIB1 e CD34 no carcinoma de próstata localizado. Curitiba. Dissertação de Doutorado, Setor de Ciências da Saúde, Universidade Federal do Paraná.

[15] Oesterling, J.E., Martin, S.K., Bergstrahl, E.J. and Lowe, F.C. (1993) The Use of Prostate-Specific Antigen in Staging Patients with Newly Diagnosed Prostate Cancer. JAMA, 269, 57-60. https://doi.org/10.1001/jama.1993.03500010067033

[16] Gomes, S.R., Melo, D.A., Soares, C.P.A., Motta, C.E., Benchimol, N.R.A. and Rainho, C.A.C. (2015) Análise da influência da densidade do PSA > 0.15 na progressão do câncer de próstata nos pacientes em vigilância ativa. UrominasRevista Cientifica de Urologia da SBU-MG, 54-60. 
Submit or recommend next manuscript to SCIRP and we will provide best service for you:

Accepting pre-submission inquiries through Email, Facebook, LinkedIn, Twitter, etc. A wide selection of journals (inclusive of 9 subjects, more than 200 journals)

Providing 24-hour high-quality service

User-friendly online submission system

Fair and swift peer-review system

Efficient typesetting and proofreading procedure

Display of the result of downloads and visits, as well as the number of cited articles Maximum dissemination of your research work

Submit your manuscript at: http://papersubmission.scirp.org/

Or contact jbm@scirp.org 